\title{
The roles of myxomycetes in ecosystems
}

\begin{abstract}
Myxomycetes; a small group of organisms with amorphous, multinucleate and protoplasmic mass are generally found on decaying or living plant materials. Myxomycetes are cosmopolitan living organisms in the world and they have very important roles in the ecosystem. In this study is given in information about their role in the ecosystem of Myxomycetes.
\end{abstract}

Keywords: myxomycetes, ecosystems, plantae, animalia, fungi, myxogastrids.
Volume 6 Issue 3 - 2018

\author{
Hayri Baba,' Mustafa Sevindik ${ }^{2}$ \\ 'Department of Biology, Mustafa Kemal University, Turkey \\ ${ }^{2}$ Department of Biology, Akdeniz University, Turkey
}

Correspondence: Mustafa Sevindik, Department of Biology,

Faculty of Science, Akdeniz University

Antalya, Turkey, Tel +90 5327 484228,

Email sevindik27@gmail.com

Received: March II, 2017 | Published: May 04, 2018

\section{Introduction}

Myxomycetes (acellular, non-cellular, plasmodial-true slime molds, or myxogastrids) are a small group of organisms, including 998 species distributed worldwide ${ }^{1}$ and 262 of which are prevalent in Turkey. ${ }^{2}$ Myxomycetes are classified in the kingdoms of Plantae (class Myxomycota) and Animalia (class Mycetozoa). Because, myxomycetes are typically found in the same habitats as fungi and they considered as a taxon within the kingdom Fungi (class Myxomycetes). Unlike fungi, myxomycetes do not excrete extracellular, digestive enzymes, and the myxomycetes do not play a role in the environment as decomposers or pathogens. ${ }^{3}$ Bauldauf \& Doolittle ${ }^{4}$ conducted a phylogenetic analysis on highly conserved, elongation factor 1-alpha (EF-1 $\alpha$ ) gene sequences and demonstrated that myxomycetes are not fungi. ${ }^{4}$ Physiological, morphological, historical, and genetic analyses support the classification of myxomycetes in the kingdom Protoctista along with other eukaryotic microorganisms. ${ }^{5}$

The life cycle of a myxomycete includes two morphologically distinct trophic stages, one consisting of uninucleate amoebae (with or without flagella), and the other consisting of a distinctive multinucleate structure; the plasmodium. ${ }^{6}$ The plasmodium feeds on bacteria, fungal hyphae and other microorganisms. Consequently, a broad spectrum of microbes can serve as nutrient organisms. Bacteria are certainly the most common among these nutrients. Myxomycetes (swarm cells, myxamoebae, and plasmodia) are phagotrophic bacteriovores and fungivores. They could even utilize some organic matter. ${ }^{7,8}$ The feeding behavior of myxamoebae/swarm cells indicates that they would ingest only spores within a certain size range, however it was observed that the myxomycete species are not specialized on adequately sized spores. ${ }^{9}$ It is less likely that myxomycetes would be useful as biocontrol agents, since they lack specificity in their food sources and are not able to penetrate hyphae. Their presence is associated with decaying or living plant material in terrestrial forest ecosystems. Humidity and temperature play a significant role in their diversity and abundance, and it was considered that certain physical and biotic factors such as light density, substrate $\mathrm{pH}$, environmental pollution and the availability of bacteria, fungi, and insects are also involved. The environmental pollution and the multiplication of pollutants also reduce Mycetozoa diversity. ${ }^{10}$
Slime molds are important, because, similar to fungi, they accumulate high metals in their cells. ${ }^{11}$ The massive aethalium of Fuligo septica contains billions of spores inside a thick calcium carbonate crust and also has a large yellow plasmodium that may serve as an experimental model to study the uptake and concentration of heavy metals such as the hyper-accumulation of zinc. Furthermore, barium, cadmium, iron, manganese, and strontium were found in F. septica in lesser but still significant amounts but much greater when compared to macromycetes and micromycetes. ${ }^{12}$ The biochemical detoxification mechanism associated with highly toxic zinc levels in F. septica and the cloning of the genes involved could be used in plants with greater biomass for bioremediation of polluted soils. It is possible that a Biotic Pollution Index could be developed using myxomycete species clusters and species richness associated with bark $\mathrm{pH}$ values taken from different living tree species. ${ }^{13}$

Young aethalia of Reticularia lycoperdon, and Fuligo septica plasmodium were used as a human nutrient in Mexico..$^{14,15}$ It is referred to by the popular name of "caca de luna" or translated into English as "feces of the moon." The scrambled-egg-like stage is fried with onions and peppers much like scrambled eggs and eaten on a tortilla. Other species such as Lycogala epidendrum also have an aethalium, which can grow up to $2-3 \mathrm{~cm}$, usually form large colonies, and for this reason, they are used as food sources in certain regions of Ecuador. ${ }^{16}$ Some Myxomycete spores such as Fuligo septica, Stemonitis fusca are aeroallergens. ${ }^{11}$

Chemical studies on the secondary metabolites of the myxomycetes demonstrated that myxomycetes have developed rather unique secondary metabolites. Almost 100 natural compounds including their chemical structures and biological activities are described; Lipids, Fatty acid amides and derivatives, Alkaloids, Amino acids and peptides, Naphthoquinone pigments, Aromatic compounds, Carbohydrate compounds, Terpenoid compounds. These compounds include; inhibitory effect against cancer cells, having antimicrobial activity against fungi and bacteria, has an antibiotic effect, cytotoxic effect, used to develop of medicines.

Slime molds consume bacteria and the other minute organisms, but they also provide favorable substrates and shelters for various species of fungi and insects, mainly Coleoptera (beetles), Latridiidae and Diptera (flies). In fact, certain beetle species use not only the 
spores but also the plasmodia of slime molds as a nutritional source. ${ }^{17}$ Latridiidae may lay their eggs in sporophores, aethalia and plasmodia; large downy colonies of myxomycetes may provide good cover for larvae and adults. Insects carry fungus spores to long distances. ${ }^{18}$ It is known that some small fungal species, when used as a food substratum, develop and sporulate on the surface of myxomycete fruit bodies. ${ }^{19,20}$

13 species of myxomycetes were recorded on 9 species of moss and 3 species of liverwort associated with woody substrata in Crimean Nature Reserve. ${ }^{13}$ Woody substrata covered with bryophytes provide favorable conditions for development of slime molds, particularly on account of the fact that their highly humid myxomycetes and bryophytes are purely accidental, arising due to slime molds, and bryophytes are both well-adapted to develop on the same substrata (bark or wood), where slime molds can complete their full life cycle from plasmodia to sporophores stages. This function benefits not only the myxomycetes but also the bacteria, algae and protozoa on which they feed. ${ }^{13,21,22}$ The myxomycetes produce sporophores and aethalia from plasmodia in drier areas on the bryophyte open surfaces. Bryophytes associated with myxomycetes, thus seem neither to benefit nor be damaged by them. Bryophytes associated with slime molds continue normal growth and reproduction, while the myxomycetes have a favorable biotope in the bryophytes communities. ${ }^{13}$ Interrelations between the bryophytes and the slime molds are, thus, generally positive and may be classified as commensal; unilateral use of one species by another without causing damage to the former.

Co-existence and interaction between slime molds, beetles, bryophytes and fungi possess specific features for every pair of interacting organisms. Insects may be either obligate or facultative feeders on slime molds; and the relations between slime molds and wood-inhabiting fungi are neutral. ${ }^{13}$

\section{Conclusion}

With the work to be done in this context, Myxomycetes can be obtained more information about the role in the ecosystem. Future research is also needed to determine the biological potentials of myxomycetes, which have many effects in the ecosystem and consequently produce many secondary metabolites in the body.

\section{Acknowledgements}

None.

\section{Conflict of interest}

Author declares there is no conflict of interest.

\section{References}

1. http://www.nomen.eumycetozoa.com

2. Baba H. Some Mycetozoa (Myxomycetes) members from zorkun high plateau (Osmaniye). Anatolian Journal of Botany. 2017;1(2):37-40.

3. Keller HW, Braun KL. Myxomycetes of Ohio: Their systematics, biology and use in teaching. Ohio Biological Survey Bulletin New Series. 1999; 13(2):1-182.
4. Baldauf SL, Doolittle WF. Origin and evolution of the slime molds (Mycetozoa). Proc Natl Acad Sci USA. 1997;94:12007-12012.

5. Everhart SE, Keller HW. Life history strategies of corticolous myxomycetes: the life cycle, fruiting bodies, plasmodial types, and taxonomic orders. Fungal Diversity. 2008;29:1-16.

6. Baba H. Diversity and Ecology of Myxomycetes in Antakya-Hatay (Turkey). Mantar dergisi. 2012;3(1-2):5-11.

7. Ing B. The phytosociology of myxomycetes. New Phytologist. 1994;126:175-202.

8. Ergul CC, Dulger B, Akgul H. Myxomycetes of Mezit stream valley of Turkey. Mycotaxon. 2005;92:239-242.

9. Olive LS. Protostelia (Protostelids). In: Olive LS, editor. The Mycetozoans. Academic Press, San Franzisco, New York; 1975:1143.

10. Ko KTW, Stephenson SL, Hyde KD, et al. Influence of Seasonality on the occurrence of Myxomycetes. Chiang Mai J Sci. 2011;38:71-84.

11. Keller HW, Everhart SE. Importance of myxomycetes in biological research and teaching. Fungi. 2010;3:1-16.

12. Stijve T, Andrey D. Accumulation of various metals by Fuligo septica (L) Wiggers and by some other slime molds (myxomycetes). Australasian Mycologist. 1999;18(2):23-26.

13. Dudka IO, Romanenko KO. Co-existence and interaction between myxomycetes and other organisms in shared niches. Acta Mycologica. 2006;41(1):99-112.

14. Lopez A, Garcia H, Herrador JL. Nuevos registros de hongos comestibles de la region del Cofre de Perote, Estado de Veracruz. (Abstract) Page 30 in Primer Congresso Nacional de Mycologia. Sociedad Mexicana de Micologia. Xalapa, Vercruz, Mexico; 1982.

15. Villarreal L. Algunas especies de Myxomycetes no registradas del estado de Veracruz. Boletín de la Sociedad Mexicana de Micología. 1983;18:153-164.

16. Rodríguez Palma MM, Montoya A, Kong A, et al. The Edibility of ReticulariaLycoperdon (Myxomycetes) in Central Mexico. J Food Sci Nutr. 2017;3:25.

17. Stephenson SL, Stempen H. Myxomyctes - A handbook of slime molds. Oregon (Timber Press), Portland; 1994:183.

18. Btackwell M, Waa JV, Reynolds M. Survival of myxomycete sclerotia after exposure to high temperatures. Mycologia. 1984;76(4):752-754.

19. Stephenson SL, Kalyanasundaram I, Lakhanpal TN. A comparative biogeographical study of myxomycetes in the mid-Appalachians of eastern North America and two regions of India. J Biogeogr. 1993;20(6):645-657.

20. Ergül CC, Akgül H. Myxomycete diversity of Uludağ national park, Turkey. Mycotaxon. 2011;116(479):1-16.

21. Ergul CC, Dulger B, Oran RB, et al. Myxomycetes of the western Black Sea Region of Turkey. Mycotaxon. 2005;96:362.

22. Dembitsky VM, Rezanka T, Spızek J, et al. Secondary metabolites of slime molds (myxomycetes). Phytochemistry. 2005;66(7): 747-769. 